UDC: 005.95/.96:316.774

https://doi.org/10.18485/akademac_hrmo.2021.ch5

\title{
УНАПРЕЪЕЊЕ ЉУДСКИХ ПОТЕНЦИЈАЛА У МЕДИЈСКИМ ОРГАНИЗАЦИЈАМА
}

\author{
Маја М. Војиновић ${ }^{1}$
}

Сажетак: Чињеница је да живимо у глобалном друштву у којем се знање, идеје и информације размењују путем различитих медија масовне комуникације. Масовна комуникација повезује људе на различитим светским меридијанима кроз разноврсне форме и садржаје свог деловања и омогућава нам да анализирамо и мењамо токове личних размишљања и уверења. Овај рад има за циљ да анализира појединачне компоненте везане за рад медијских организација и људи у њима. Акценат стављамо на људски фактор који има супериорну моћ да кроз медијске организације реалност спољашњег света преточи у вест својим објективним, веродостојним, интерпретативним деловањем. У раду су обрађене теме људског потенцијала у медијским организацијама, начини унапређења рада процесом регрутације, селекције и обуке, али свакако и теме теорија о масовној комуникацији које доприносе напретку у раду медијских организација.

Кључне речи: људи, медијске организације, регрутација, селекција, обуке, масовно комуницирање

\section{УВОД}

Како бисмо на што свеобухватнији начин одговорили на задату тему, неопходно је прво да дефинишемо кључне елементе наслова рада. У складу са тим, овај рад има задатак да одговори на следећа питања, а то су: шта је људски потенцијал, шта су медијске организације и на који начин је могуће унапредити рад медијских организација. Свакако да је незаобилазна тема у овом научно-истраживачком поступку дефинисати медијски систем. „Полазећи од епистемолошких премиса постављених у општој теорији система, систем се може одредити као динамички међузависни скуп елемената, који се налазе у развојној интеракцији. Осим унутрашње

\footnotetext{
1 Факултет за менаџмент, Сремски Карловци, Универзитет „Унион Никола Тесла“, Београд,
} e-mail:vojinovic@famns.edu.rs 
динамике и развојне интеракције структуралних елемената система, сваки систем је у интеракцији са другим системима, који се, сви заједно, појављују као структурални елементи, тј. подсистеми већег система."2

Уколико на овакав начин схватимо медијски систем, онда јасно уочавамо да се медијски систем не може одвојити од друштва у којем делују медијске организације и да управо оне и настају у оквирима појединачних медија који представљају есенцијалну компоненту њиховог постојања.

\section{Људска компонента}

Ни једна организација не би могла да функционише без људи. Људски фактор је инкорпориран у рад сваке медијске организације, било да се ради о ТВ кући, новинској агенцији, радијској станици или некој савременој (мас) медијској творевини попут портала, Веб платформи, Интернета, мултимедије, дигиталних формата итд. Отуда се и развила област науке под називом Менаџмент људских ресурса, као израз потребе да се проуче сви аспекти запошљавања унутар медијских организација. Неколико важних момената у научно-технолошким променама је утицало на развој менаџмента људских ресурса, а то су: „колективно преговарање, научно управљање, развој индустријске психологије, теорија међуљудских односа, бихејвиористичке науке."3

Колективно преговарање је настало као последица деловања синдикалног удруживања радника које је изнедрило штрајкове и законодавни систем. Научно управљање је било везано за повећање продуктивности рада и увођење награда према степену ангажованости запослених. Развој индустријске психологије је резултат потребе да се кроз психолошке тестове утврде ставови појединаца о послу, тестови личности, однос према раду са психолошког аспекта, док је теорија међуљудских односа створила повољан амбијент за удруживање и стварање групација ради повећања продуктивности на послу. Бихејвиористичке науке се баве понашањем појединаца, запослених унутар организација и наглашавају индивидуалне карактеристике запослених, њихове ставове, мотивацију, жељу за радом, а све то у циљу унапређења рада запослених.

„Током свог развоја научна област менаџмента људских ресурса је претендовала да створи изразито фрагментирану област изучавања, јер су истра-

2 Извор: медијски систем, https://www.knjigaknjiga.com/proizvod-struktura-i-dinamika-medijskog-sistema-srbije.htmly: Мирко Милетић (2014): Структура и динамика медијског система Србије, Београд: Хрестоматија ISBN 978-86-6293-033-0. Приступљено: 17.12.2021.

3 Суша, Б. (2009). Менаџмент људских ресурса. Нови Сад: Cekom- books d.o.o, стр.16. 
живачи своју пажњу усмеравали на различита питања, почев од појединачних активности (регрутовање, селекција, награђивање, тренинг, оцењивање) ка стратегијском схватању потребе повезивања управљања људским ресурсима и пословне стратегије предузећа." ${ }^{4}$

\section{Регрутовање кадрова}

Један од начина да се унапреди рад медијских организација јесте да се запосле високо квалификовани људи. Када се створи потреба унутар једне медијске куће за новим радним местом, онда се том процесу приступа систематично и професионално. У зависности од врсте радног места, профилише се и кандидат са потенцијалним, неопходним карактеристикама од нивоа образовања, стручне квалификације, знања које поседује, способности, опште интелигенције, па до физичког изгледа, карактеристика, личних склоности и специфичних способности, а све у циљу унапређења квалитета рада. Наравно да је процес регрутације двосмеран и да у њему учествује медијска организација и потенцијални, заинтересовани кандидат.

„Кадровски менаџмент кроз процес регрутовања одређује: извор регрутовања; квалитет радне снаге; поседовање индивидуалних или тимских особина; развојни или актуелни потенцијали кандидата; спремност за улагање ради обезбеђивања квалитетног кадра; критеријуми селекције и слично."

Исти аутор даље наводи да су у протеклом периоду послодавци давали предност кандидатима који поседују: „развојне потенцијале; креативност; флексибилност; иницијативност; комуникативност; аналитичке способности и наклоњеност за тимски рад. Тренутна знања и способности кандидата стављају се у други план."6

Исто, 17.

Исто, 175.

6 Исто, 176. 


\section{Селекција кадрова}

Кадровска селекција ${ }^{7}$ је једна од најважнијих сегмената у процесу управљања људским ресурсима. Начин како и када ће се она вршити, одлучује сектор за кадровску политику медијског предузећа. Он обухвата тим стручних сарадника из области медија, психологије, права и осталих, релевантних подручја образовања. Уз помоћ унапред утврђених правила, техника и стандардизованих метода испитивања, селекција се врши између неколико квалификованих кандидата, који изборним већањем улазе у најужи круг избора. Процес селекције није самосталан процес. Он се обавља у складу са осталим процесним поступцима, као што су: планирање кадрова, обука, развој, оријентација, социјализација, анализа пословања и успешности једног медијског предузећа.

Оно што чини саставни део сваког процеса селекције јесте финални чин у одабиру најбољег кандидата који има изузетне способности, компетенције и изражене карактеристике личности. Под компетенцијом подразумевамо ону особину личности која дела стручно, зналачки, ефикасно и даје резултат брзо и учинковито.

\section{Обука}

Поред регрутације и селекције кадрова који су предиспонирани на ефективну продуктивност у раду: објективност, тачност, прецизност, веродостојност, обуке су незаобилазни сегмент у процесу планирања пословног поступка. Обуке се односе на стицање практичних знања и вештина који су неопходни у процесу рада и руковођења, у складу са правилима и прописима унутар медијских организација. Да би се стекло искуство у практичном раду, неопходно је бити „на терену”и искусити све изазове и проблеме са којим се запослени у медијским организацијама свакодневно суочавају, нарочито, ако узмемо у обзир чињеницу да је медијска организација део једног општег медијског система који у различитим временима мења токове свог (мас) медијског садржаја и пласмана.

7 Селекција људских ресурса је идентификација и избор између више кандидата, оних чија знања, способности, особине личности, мотивација и друго у највећем степену одговарају захтевима посла и циљевима компаније. Селекција је процес у коме се врши избор расположивих кандидата за одређени посао и доношење одлуке о запошљавању. Извор: https://edukacija.rs/menadzment-ljudskih-resursa/profesionalna-selekcija Приступљено: 17.12.2021. 


\section{Медијски системи}

Да би једна медијска организација могла да ради, она мора да испуни одговарајуће услове. Први је да поштује закон и устав земље у којој живи и ради. Правни прописи којима се регулише медијски систем, јавно комуницирање, техничке могућности, рад електронских медија, грађанска права и слободе су прецизни и јасни. Поред правних прописа, свака медијска кућа има и понаша се у складу са етичким нормама, принципима и у складу са новинарским кодексом који се базира на истинитим, тачним, објективним, веродостојним, проверљивим информацијама. Неке норме, правила, могу се интерно усаглашавати унутар појединачних медијских кућа , али у складу са основним законом.

У нашој земљи има много медијских организација (удружења, асоцијација, регулаторних тела и др.), али ћемо навести неке:

AНЕМ - Асоцијација независних електронских медија,

НУНС - Независно друштво новинара Србије,

РНИДС - Регистар националног Интернет домена Србије,

НДНВ - Независно друштво новинара Војводине,

Савет за штампу,

Републичка радио - дифузна агенција, итд. ${ }^{8}$

\section{Теорија дневног реда-теорија агенде}

Денис Меквејл (Denis McQuail), у својој књизи „Теорија масовне комуникације", пише да постоје многе теорије о масовној комуникацији. Навешћемо неке од њих, а то су: теорија о социјалној сегментарности масовне публике, теорија симболичке интеракције, теорија користи и задовољства, теорија о двостепеном току масовног комуницирања, теорија чувара капије, итд.

Задржаћемо се на теорији дневног реда или теорији агенде у масовном комуницирању. Овом теоријом су се педесетих година XX века бавили Пол Лазарсфелд (Paul Lazarsfeld) и Роберт Мертон (Robert Merton). Tеорија дневног реда „представља покушај да се редефинишу постулати о масовном комуницирању настали у оквиру критичке теорије друштва. Према овој теорији, две су основне функције медија масовног комуницирања:

8 Извор: Медијске организације, http://arhiva.mc.rs/korisne-adrese---medijske-organizacije.34. html, приступљено: 04.12.2021.

9 McQuail, D. (2009). McQuail's Mass Communication Theory. London: Sage publication Itd. 
додељивање статуса и наметање друштвених норми."10 Масовни медији придају важност одређеним темама, проблемима, организацијама и то на начин што неке теме упорно потенцирају и стављају на дневни ред, неке веома мало или нимало, стога закључујемо да се успоставља хијерархија према степену важности која долази из највиших врхова медијског система.

Исти аутор даље наводи да се масовним медијима и „целином посредованих садржаја сугеришу норме и вредности, који су у складу са нормативним поретком и преовлађујућим вредносним системом у друштву. Појединац који конзумира медијске садржаје „предаје се погрешном уверењу да знати за дневни проблем значи учинити нешто у вези са њим."11

Увиђамо да се теорија дневног реда или теорија агенде развијала постепено, слојевито и да је увек изнова добијала неку нову димензију. Континуитет дешавања у простору и времену, нови догађаји могу утицати на већ постављену агенду, било на позитиван или негативан начин. Претпоставка је да нећете моћи баш увек људе да убедите у оно што им сервирате и што је на дневном реду. Доступност вишеструких информација, такође утиче на постављање дневног реда, јер различити телевизијски канали, новине, онлајн извори деле сопствени програм који није сличан.

У књизи Дениса Меквејла „Теорија масовних комуникација”, аутор истиче име Шофела (Scheufele), који је предлагао и говорио о ефектима медијског оквира који су настали „као резултат између три врсте учесника"12. Са једне стране имамо медијске организације и изворе интересовања, на другој страни су новинари и као трећег актера наводи публику. Он, такође каже, да постоје две врсте оквира, а то су медијски и индивидуални оквир. Оба оквира могу бити зависна или независна. Према овом моделу, постоје четири међузависна процеса оквира који укључују сва три актера. Као прво, он каже да постоји конструкција и употреба медијских оквира од стране новинара и осталих који раде у новинским кућама под свакодневним притисцима и који се константно баве изворима и примењују вредност вести и начин спознаје вести на извештај о догађају. Друго, постоји и пренос једног таквог "уоквиреног" извештаја на публику и као треће наводи прихватање одређених оквира од стране чланова публике са последицама на ставове и понашање.

Управо због свега претходно наведеног, теорија дневног реда или теорија агенде нас упућује да је неопходно унапређивати људски потенцијал у медијским организацијама, јер људи су ти који реалност, објективност, чињенично стање на терену треба да усвоје и пренесу на аудиторијум који очекује правовремену, тачну и веродостојну информацију, без изузетка.

10 Милетић, М. (2012). Комуниколошки лексикон. Београд: Мегатренд Универзитет, стр. 342.

11 Исто, 342-343.

12 McQuail, D. (2009). McQuail's Mass Communication Theory. London: Sage publication Itd, p.511. 


\section{ЗАКЉУЧАК}

На крају можемо да закључимо да унапређење људског потенцијала у медијским организацијама није лак задатак. Поред честих регрутација, селекције и обуке кадрова за бољу учинковитост и већу успешност у раду, медијске куће се суочавају и са другим проблемима попут социјалне политике, друштвеног контекста, економских нестабилности и са тим у вези покушавају да одрже ниво успешности у презентовању објективне реалности. Теорија дневног реда најбоље идеу прилог овој тези и указује на то да аудиторијум није увек лако убедити у пласирани садржај, што јесте предност за истраживачко и аналитичко новинарство; да трага за дубљим и слојевитијим значењима и тумачењима, а не само за инстант, адхок информацијама. Ово је уједно и позив за новинаре који непогрешиво поштују етички кодекс да само радом на себи, усавршавањем, продубљивањем постојећих знања, дају допринос поспешивању рада унутар медијских организација.

Намера ауторке овог рада није да одговори на сва питања везана за ову актуелну, друштвену тему, нити је то могуће, али јесте да укаже на кључне проблеме и да̂ евентуалне смернице за даље анализе у овој области.

\section{ЛИТЕРАТУРА}

1. Милетић, М. (2012). Комуниколошки лексикон. Београд: Мегатренд Универзитет.

2. McQuail, D. (2009). McQuail's Mass Communication Theory. London: Sage publication Itd.

3. Суша, Б. (2009). Менаџмент људских ресурса. Нови Сад: Cekom- books d.o.o.

\section{Вебографија:}

1. Медијски систем. https://www.knjigaknjiga.com/proizvod-struktura-i-dinamika-medijskog-sistema-srbije Приступљено: 17.12.2021.

2. Медијске организације. http://arhiva.mc.rs/korisne-adrese---medijske-organizacije.34.html Приступљено: 04.12.2021.

3. Селекција. https://edukacija.rs/menadzment-ljudskih-resursa/profesionalna-selekciја. Приступљено: 17.12.2021. 